\title{
Pelatihan pembuatan kue serabi aneka rasa pada ibu rumah tangga di Kabupaten Bantaeng
}

\author{
Ratnawati Tawani ${ }^{1}$, Syamsidah ${ }^{2}$ \\ ${ }^{1,2}$ Fakultas Teknik, Universitas Negeri Makassar
}

\begin{abstract}
This training aims to: 1) be more skilled in the world of catering 2) develop the potential that is already owned for its own and commercial uses independently. 3) increase productivity with catering and business activities. The training on empowering housewives through training in making pancakes of various flavors in Bantaeng Regency is a partnership program to the community as a solution to the problem of less productive housewives in Bantaeng Regency. The target audience for the training was 15 housewives in Bantaeng Regency. The training method is done in the form of lectures, questions and answers, discussions and practices. After conducting training to housewives through making pancakes of various flavors in Bantaeng Regency, it can be concluded that as many as 15 trainees have understood and understood well how to make various flavors of pancake cakes directly, both for themselves and others. The trainees not only were skilled in making pancakes of various flavors, production methods and marketing techniques also provided inspiration for the importance of empowering housewives through continuous catering training.
\end{abstract}

Keywords: training, various pancake flavor, housewife

\section{PENDAHULUAN}

Kabupaten Bantaeng yang terletak di bagian selatan Provinsi Sulawesi Selatan terletak pada titik $5^{\circ} 21^{\prime 2} 23^{\prime \prime}-5^{\circ} 35^{\prime 2} 26^{\prime \prime}$ Lintang Selatan dan

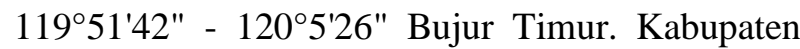
ini berjarak $125 \mathrm{Km}$ ke arah selatan dari Kota Makassar.

Kabupaten Bantaeng terkenal dengan sumber daya alamnya, baik hasil pertanian, perkebunan, maupun perikanan. Produktivitas padi di Kabupaten Bantaeng, Sulawesi Selatan saat musim panen Maret-April 2016 mencapai 9,4 ton gabah per hektar. Tertinggi dalam 10 tahun terakhir (Kamil, 2010).

Ibu-ibu rumah tangga di Kabupaten Bantaeng sebagian besar menghabiskan waktunya di dalam rumah mengurus suami dan anak-anak mereka. Ketika urusan rumah tangga telah selesai tidak ada lagi kegiatan lain, kecuali bercengkrama dengan tetangga dan berbagai aktifitas di lingkungannya yang tidak produktif.

Dilihat dari tingkat pendidikannya, ibu-ibu rumah tangga mempunyai pendidikan yang relatif rendah, rata-rata berpendidikan SD dan SMP, demikian juga dari segi ekonomi tergolong lemah.
Namun demikian perlu juga dimotivasi karena mereka mempunyai hasrat yang kuat untuk berubah. Hal ini diketahui setelah melakukan observasi dan wawancara di lokasi pengabdian (5 Januari 2019). Pada umumnya mereka menyambut baik keinginan kami untuk memberi pengetahuan dan keterampilan, agar mereka dapat mengisi waktu senggangnya dengan kegiatan yang produktif.

Salah satu pengetahuan yang penting diberikan kepada ibu-ibu di desa ini adalah membuat dan memproduksi kue serabi. Kue ini tergolong kue tradisional dan saat ini hampir punah dan tidak dikenal lagi oleh generasi milenial yang gemar mengkonsumsi makanan-makanan import, bersyukurlah bahwa kue serabi ini masih sering dibuat oleh generasi pendahulu sehingga masih bertahan dan ke depan perlu dikembangkan agar dapat bertahan karena disamping enak rasanya, juga adalah bagian dari tradisi dan kebudayaan yang perlu dilestarikan.

Bahan baku pembuatan kue ini mudah dan murah diperoleh. Sebagaimana diketahui bahwa tidak jauh dari lokasi tempat pengabdian ini dilakukan terdapat pasar yang setiap harinya 
tersedia bahan baku seperti tepung beras, tepung terigu dan kelapa untuk dibuat santan. Selain bahan dasar yang mudah diperoleh, bahan tambahan food additive juga tersedia cukup banyak dan mudah diakses karena berlokasi disekitar tempat tinggal mitra (Winarno, 1995; Syamsidah et al,. 2016).

Dalam rangka lebih meningkatkan nilai tambah produk mitra, pelatihan membuat kue serabi ini juga dirangkaikan dengan upaya untuk memberi pengetahuan dan ketrrampilan bagaimana menjual dan memasarkan produk, oleh sebab itu materi pelatihan mengenai kemasan dan pemasaran juga akan diberikan, mengingat bahwa salah satu masalah yang dihadapi ibu-ibu rumah tangga di desa ini adalah kemampuan kreatifitasnya yang rendah sehingga perlu diberi pengetahuan dan keterampilan agar bisa berkreasi dan meningkatkan nilai tambah produk.

Berdasarkan kondisi dan karakteristik ibu-ibu rumah tangga seperti yang telah diuraikan pada analisis situasi, maka permasalahan yang dihadapi oleh ibu-ibu rumah tangga di Kecamatan Bonto Tiro Kabupaten Bantaeng sebagai mitra adalah:

1. Pengetahuan mitra dalam pembuatan kue serabi aneka rasa masih terbatas dan bahkan tidak mengetahui.

2. Pengetahuan tentang alat atau piranti kue serabi yang praktis masih kurang.

3. Pengetahuan tentang bahan makanan menjadi kue masih kurang.

4. Pengetahuan tentang kemasan makanan masih kurang.

5. Pengetahuan tentang managemen usaha masih rendah.

Kenyataan seperti yang ditemukan di atas menarik perhatian kami untuk melakukan pelatihan dan merubah mindset masyarakat di Kabupaten Bantaeng, sehingga nantinya akan menambah pendapatannya.

\section{METODE PELAKSANAAN}

Berdasarkan hasil identifikasi masalah dan potensi sumber daya alam di Desa Bonto Tiro Kabupaten Bantaeng, maka ada beberapa kegiatan yang berkaitan diantaranya adalah sebagai berikut:
1. Peningkatan pengetahuan mitra dalam pembuatan kue serabi aneka rasa.

2. Peningkatan pengetahuan mitra tentang alat atau piranti yang digunakan dalam pembuatan kue serabi.

3. Peningkatan pengetahuan mitra tentang bahanbahan makanan yang digunakan dalam pembuatan kue serabi aneka rasa.

4. Peningkatan pengetahuan mitra tentang kemasan makanan.

5. Peningkatan pengetahuan mitra dalam managemen usaha.

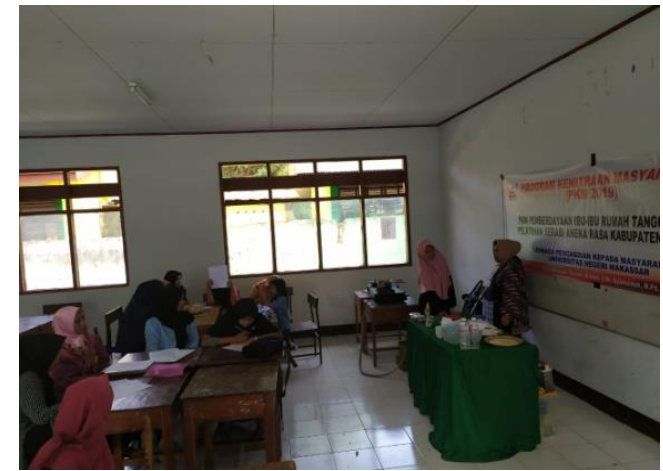

Gambar 1. Pemberian materi pada ibu-ibu rumah tangga

Pelaksanaan program menggunakan metode ceramah, tanya jawab, dan praktik pembuatan kue serabi aneka rasa.

\section{HASIL DAN PEMBAHASAN}

\section{A. Hasil Pelatihan}

Pelaksanaan kegiatan tepatnya dilaksanakan di Desa Bonto Tiro Kecamatan Sinoa Kabupaten Bantaeng Provinsi Sulawesi Selatan. Salah satu produk hasil pertanian yang sering dikonsumsi masyarakat desa Bonto Tiro adalah hasil olah beras, yaitu tepung beras. Selain itu harganya juga dapat terjangkau oleh masyarakat.

Pelatihan teori maupun praktik dapat diukur dengan beberapa indikator yang meliputi: 1) keseriusan dan kesungguhan peserta pelatihan. 2) lebih dari $80 \%$ peserta mampu memahami cara membuat serabi aneka rasa dengan baik, mampu menyajikan kue serabi. 3) setelah melakukan observasi langsung pada saat pelatihan, maka hasil yang dicapai adalah: a) Para peserta memperhati- 
kan dan menyimak secara serius materi-materi yang disajikan oleh pemateri. Beberapa peserta bertanya kepada penyaji baik ketika materi teori maupun praktik. Suasana diskusi antara penyaji dengan peserta terlihat serius dan aktif meskipun sesekali disertai dengan guyonan dari pemateri yang nampaknya terkadang lupa waktu. b) Peserta yang hadir melebihi prediksi selama pelaksanaan kegiatan.

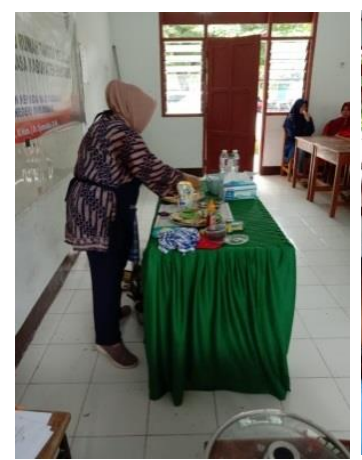

(a)

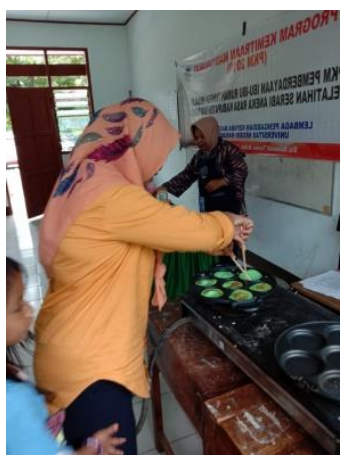

(b)
Gambar 2. Proses pembuatan kue serabi aneka rasa

\section{B. Pembahasan}

Setelah pelatihan dilaksanakan, maka nampak bahwa peserta memiliki pengetahuan dan keterampilan mengenai cara membuat kue serabi aneka rasa, ini artinya ibu-ibu rumah tangga di Kabupaten Bantaeng yang berminat untuk pelatihan pembuatan serabi aneka rasa kemudian memiliki kepercayaan diri untuk dapat membuat kue serabi aneka rasa dan memproduksinya untuk meningkatkan pendapatan mereka. Sebagaimana diketahui bahwa pelatihan ini diharapkan agar ibuibu rumah tangga yang akan membuat serabi: dapat 1) lebih terampil dalam dunia tata boga 2) mengembangkan potensi yang telah dimiliki untuk keperluan sendiri dan komersial secara mandiri. 3) meningkatkan produktifitas dengan kegiatan tata boga dan wirausaha. Pengetahuan dan keterampilan yang dimiliki oleh peserta setelah pelatihan sama halnya. dengan pemberian pendidikan jangka pendek yang menggunakan cara dan prosedur yang sistematis dan teroganisir (Bartono, 2000), pendapat lain mengatakan bahwa pelatihan merupakan suatu proses membantu orang lain dalam memperoleh skill dan pengetahuan.

Setiap manusia dilahirkan dengan potensi dan bakat namun potensi itu hanya dapat berkembang jika diberi pelatihan yang berarti, hal ini senada dengan pendapat Michael J. Jucius yang dikutip Kamil (2010) bahwa latihan adalah setiap proses untuk mengembangkan bakat, keterampilan dan kemampuan pegawai guna menyelesaikan pekerjaan-pekerjaan terentu. pelatihan oleh center for development Management dan productivity didefinisikan sebagai belajar untuk mengubah tingkah laku orang dalam melaksanakan pekerjaan/tugas yang dilakukan seseorang. Dengan demikian pelatihan pada dasarnya merupakan suatu proses memberikan bantuan bagi para pekerja untuk mengusai keterampilan khusus atau membantu untuk memperbaiki kekurangan dalam melaksanakan pekerjaan mereka.

Tranggono (1988) menyatakan bahwa pelatihan adalah proses memberikan bantuan bagi para pekerja untuk mengusai keterampilan khusus atau membantu untuk memperbaiki kekurangannya dalam melaksanakan pekerjaan. Fokus kegiatannya adalah untuk meingkatkan kemampuan kerja dalam memenuhi kebutuhan tuntutan cara kerja yang paling efektif masa sekarang.

Memperhatikan dan mencermati beberapa pendapat di atas nampak bahwa tujuan pelatihan tidak hanya untuk meningkatkan pengetahuan, keterampilan dan sikap, akan tetapi juga untuk mengembangkan bakat seseorang, sehingga dapat melakukan pekerjaan sesuai dengan mengembangkan yang dipersyaratkan. Tranggono (1988) menjelaskan bahwa tujuan umum pelatihan sebagai berikut: 1) untuk mengembangkan keahlian, sehingga pekerjaan dapat diselesaikan dengan lebih cepat dan efektif, 2) untuk mengembangkan pengetahuan sehingga pekerjaan dapat diselesaikan secara rasional dan 3) untuk mengembangkan sikap, sehingga menimbulkan kemauan kerjasama dengan teman-teman pegawai dan dengan manajemen (pimpinan).

Masih terkait dengan tujuan dan manfaat pelatihan, Kamil (2010) mengemukakan bahwa tujuan utama pelatihan adalah untuk memperbaiki kinerja dan meningkatkan produktivitas, pelatihan 
ini merupakan gabungan antara teori dan praktek secara teoritis penelitian mengenai cara pembuatan kue serabi aneka rasa dalah satu upaya untuk memberikan pengetahuan dan keterampilan mengenai pembuatan serabi aneka rasa, produksi dan pemasarannya. Pelatihan ini merupakan bentuk refrektif berupa tindakan tertentu agar dapat meningkatkan produktivitas ibu rumah tangga di Kabupaten Bantaeng.

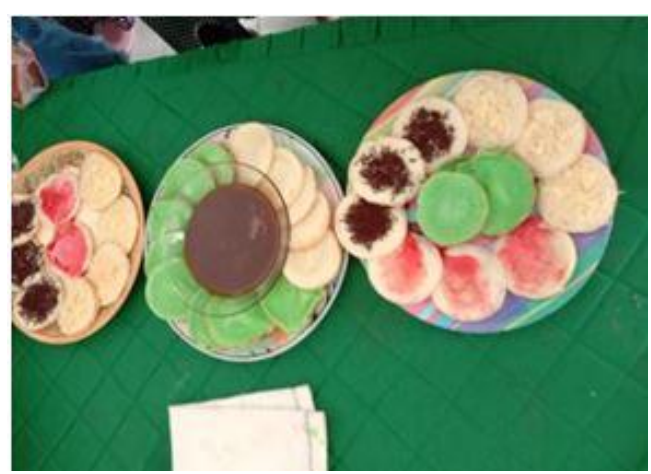

Gambar 3. Hasil kue serabi aneka rasa

\section{Evaluasi dan Hasil yang Dicapai}

Evaluasi kegiatan melalui pengamatan langsung pada saat pelatihan teori maupun praktek berlangsung yang dapat diukur dengan beberapa indikator:

1. Keseriusan dan kesungguhan peserta pelatihan yakni para ibu-ibu rumah tangga di Kabupaten Bantaeng.

2. Lebih dari $80 \%$ peserta telah mampu memahami cara membuat kue serabi aneka rasa dengan baik. Demikian pula peserta mampu mempraktikkan cara pembuatannya secara langsung.

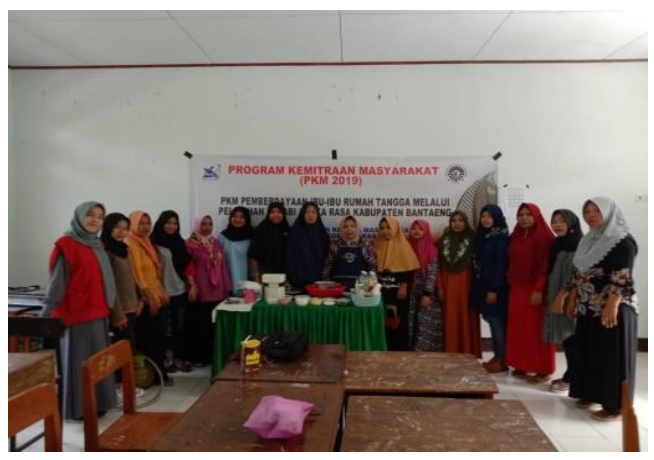

Gambar 4. Foto bersama peserta
Setelah melakukan observasi langsung pada saat pelatihan, maka hasil yang dicapai adalah peserta memperhatikan dan menyimak secara serius materi yang disajikan oleh pemateri. Beberapa orang bertanya kepada penyaji baik ketika materi maupun praktik. Suasana diskusi antara penyaji dengan peserta terlihat serius dan aktif meskipun sesekali disertai guyonan dari pemateri yang nampaknya terkadang lupa waktu.

\section{KESIMPULAN}

Setelah melakukan pelatihan melalui kegiatan pemberdayaan ibu-ibu rumah tangga melalui pelatihan pembuatan kue serabi aneka rasa di Kabupaten Bantaeng maka dapat disimpulkan bahwa sebanyak 15 orang peserta pelatihan telah mengerti dan memahami dengan baik cara pembuatan kue serabi aneka rasa secara langsung baik untuk diri sendiri maupun orang lain. Selanjutnya peserta pelatihan bukan saja telah terampil dalam membuat kue serabi aneka rasa, cara pengolahan, penyajian dan teknik pemasaran juga memberikan inspirasi pentingnya pemberdayaan ibu-ibu rumah tangga melalui pelatihan tata boga secara berkelanjutan.

\section{DAFTAR PUSTAKA}

Syamsidah et al. 2016. Dasar Boga. Makassar: Agus Corp. Bartono, PH, 2000. Pengantar Pengolahan Makanan. Jakarta. Pt.Pertja.

Kamil, M. 2010. Model Pendidikan Dan Pelatihan. Bandung: Alfabeta.

Tranggono (1988). Bahan Tambahan pangan (Food Additives). Pusat Antar Pangan dan Gizi Universitas Gadjah Mada Yogyakarta.

Winarno, F.G. 1995. Enzim Pangan. Jakarta: PT. Gramedia Pustaka Utama. 